\title{
Melancholic Vision and Utopian Imagination: Amma Ariyan and Left-wing Culture in Kerala in the 1970s
}

\author{
P. Muhammed Afzal
}

Assistant Professor, Department of Humanities and Social Sciences, Birla Institute of Technology and Science, Pilani (BITS Pilani), Pilani, Rajasthan, India-333031. ORCID ID: 0000-0002-9989-6251 Email: muhammed.p@pilani.bits-pilani.ac.in

\begin{abstract}
Situating the Malayalam film Amma Ariyan in the context of radical Left politics in Kerala during the "long 1970 s", this paper argues that Left-wing cultural productions during the period offered a melancholic vision of history that sustained a utopian imagination. In popular discussions, the 1970s is seen as a period of "misguided adventurism" and defeat, and the nostalgia for the period is treated as a paralyzing, backward looking attitude. Drawing on contemporary scholarship on Left melancholy, nostalgia, and utopia, this paper looks back at the 1970s from a perspective where melancholia is a stance that offers a critical vision of the past as well as the future. This paper argues that the "failed heroes" in Left-wing cultural productions in the 1970s refused to "resign themselves to ... the inevitable and 'natural' character of the most monstrous inequalities". This "refusal to be realistic" has been very central to the sustaining of a utopian imagination which acquires more significance in the context of the perceived reactivation of "communist desire" in the contemporary times.
\end{abstract}

Keywords: Amma Ariyan, Radical Left, Left Melancholy, Malayalam Cinema, Kerala

\section{Introduction}

The Malayalam film Amma Ariyan (Report to Mother, 1986) directed by the avant-garde filmmaker John Abraham occupies a cult status in discussions on Malayalam cinema. The accidental death of the director soon after the release of the film elevated the film to a "cult status while also merging together the fate of the director with that of the main protagonist" (Rajadhyaksha and Willemen, 1999, p. 474). With the digital restoration of the film by the National Film Archives of India (NFAI) a few years ago the film has received an "afterlife", with more screenings and discussions of the film. However, the afterlife of the film is also owing to the nostalgia for the 1970s when radical Left politics and the cultural activism associated with it had a significant presence in Kerala. In many of the nostalgic recollections of the "long 1970s", the film and the Odessa Collective that produced the film find a mention, as a remnant of a radical past.

Owing to the unique model of film production and distribution, and the film's exploration of radical Left politics in Kerala, Amma Ariyan has been heralded as a "political film par excellence" by many commentators. As Jenson Joseph observes, "for many critics in the region, political

This Open Access article is published under a Creative Commons Attribution Non-Commercial 4.0 International License (http://creativecommons.org/licenses/by-nc/4.0/), which permits non-commercial re-use, distribution, and reproduction in any medium, provided the original work is properly cited. For citation use the DOI. For commercial re-use, please contact editor@rupkatha.com. 
cinema started and ended with John Abraham, and the activities of the film society collective that he was part of (called 'Odessa') that produced the film" (Joseph, 2020, p. 158). The film, produced through crowd funding has been seen as a model for radical filmmaking. Odessa Collective, set up by John Abraham in 1984, "funded Amma Ariyan through screenings of $16 \mathrm{~mm}$ prints of ... Chaplin's The Kid (1921) and Anand Patwardhan's Hamara Shaher (1985) in towns and villages throughout Kerala in return for small donations" (Rajadhyaksha and Willemen, 1999, p. 39). As hinted above, the reception of the film has been mediated by the cultural politics of the time, when there was a significant presence of cultural activism associated with the radical Left in Kerala (Sreejith, 2005).

In recent scholarly writings the film has been discussed in terms of the excavation of the past that the film undertakes and its implications for Left politics in the region, and the idea of the collective in the film (Parameswaran, 2015; Krishnan, 2010). In this paper, I draw on contemporary scholarship on Left melancholia, communist desire and utopia (Traverso, 2016; Dean, 2018) to situate Amma Ariyan in the context of the melancholic dimension of Left-wing culture in Kerala during the "long 1970s". This period is seen as one when the "horizon of expectation" generated by the Left movements in Kerala had begun to give way to despair, following many defeats, both at the local and global levels.

\section{Rethinking Left Melancholy and Nostalgia}

The historical space that radical Left movements and the cultural forums associated with them occupied, which is also central to the narrative of the Amma Ariyan, is often recollected with nostalgia or melancholy. Many of the first-person narratives such as memoirs that have come out in the last few years look at the period of radical Left politics as a lost dream. The nostalgia for a radical past can be seen as a global phenomenon, especially in the context of the nostalgia for 1968. However, this nostalgia has most often been seen as an impediment in the march forward. Pointing out that "throughout the last century nostalgia was cast as the antithesis of radicalism", Alastair Bonnett argues that "nostalgia has been an important but rarely acknowledged aspect of the radical imagination" (Bonnet, 2010, p. 1).

In an essay published in 1999 that engages with the debates around the "crisis of Left", Wendy Brown turns to Walter Benjamin's formulations on Left melancholia to talk about the Left's inability to move beyond its failures. Brown points out that

"Left melancholia" is Benjamin's unambivalent epithet for the revolutionary hack who is, finally, not serious about political change, who is more attached to a particular political analysis or ideal — even to the failure of that ideal — than to seizing possibilities for radical change in the present (Brown, 1999, p. 20).

One can find an echo of Brown's arguments in the demonization of the nostalgia for the 1970s in Kerala. While many other thinkers including Jodi Dean have challenged Brown's propositions, the re-evaluation of Left melancholia that Enzo Traverso offers helps us to see Left-wing cultural productions in a new light. Approaching Left-wing culture as "a combination of theories and experiences, ideas and feelings, passions and utopias" (Traverso, 2017, p. xiii), Traverso writes that 
[Left] melancholia, however, does not mean a retreat into a closed universe of suffering and remembering; it is rather a constellation of emotions and feelings that envelop a historical transition, the only way in which the search for new ideas and projects can coexist with the sorrow and mourning for a lost realm of revolutionary experiences. Neither regressive nor impotent, this left-wing melancholia should not evade the burden of the past. It is a melancholy criticism that, while being open to the struggles in the present, does not avoid self-criticism about its own past failures; it is the melancholy criticism of a left that is not resigned to the world order sketched by neoliberalism but that cannot refurbish its intellectual armory without identifying empathetically with the vanquished of history, a large multitude inexorably joined, at the end of the twentieth century, by an entire generation—or its remains—of defeated leftists (p. xiv).

The re-evaluation of Left melancholy that Traverso offers enables us to see how the history of defeats enabled the radical Left with a melancholic vision of the past which refused to mourn the passing of the object of attachment, which is the "communist idea", and make peace with the dominant order. Drawing on Traverso, I argue how the cultural productions during the "long 1970s", through their "inability to mourn", activated the critical potentialities of a melancholic vision of the past. In the sections that follow, I argue how Amma Ariyan can be seen as a text that offers a melancholic vision of the history of the radical Left in Kerala. This will be primarily advanced through a discussion of the "absent" hero of the film, Hari, whose suicide brings into existence a collective, as well as the film's exploration of the "failures" of the various people's struggles in the region. Before going into a detailed discussion of the film a brief overview of the film is due.

Amma Ariyan revolves around the suicide of Hari, a young artist and a radical Left activist and the journey that his friends and acquaintances undertake from Wayanad in north Kerala to Fort Kochi in central Kerala to inform his mother about the death. Purushan, a Nair youth from Malabar, is getting ready to leave for Delhi to pursue academic research. While bidding farewell his mother asks him to write to her regularly, wherever he goes, as "these are bad times", an allusion to the state brutalities of the period. The film progresses through his reports to the mother, which is presented in the form of soliloquies, about the events that he witnesses on his way. He boards a bus from Kozhikode town to Wayanad where his girlfriend waits for him to leave for Delhi together. But before reaching the ashram where his girlfriend stays, Purushan's journey is interrupted as the jeep in which he is travelling through the forest areas of Wayanad is stopped by the police, who ask for its possession to carry a dead body. The face of the dead body seems familiar to Purushan, but he cannot identify who it is. Learning that it is a suicide, Purushan is disturbed and climbs the hill where the young man had committed suicide. He goes to his girlfriend and tells her that he will not be able to go with her to Delhi as he wants to identify the dead body and inform the mother of the dead person. He goes to meet his journalist friend Jayan to find out the details about the dead person, but the police are yet to identify the body. From there he goes to Calicut medical college, where the dead body is kept, and meets his friend Rajan, who is leading a students' struggle against the privatisation of medical education in the state. With Rajan's help, Purushan sees the body in the mortuary. As he is still not able to identify the body, they seek the help of a senior political activist, whom others fondly call Balettan, and he identifies the person as the boy who used to play the tabla with Satyajit, the guitarist. Satyajit 
confirms that it is Hari, who used to play the tabla for him. Once they confirm the identity of the dead person, they set out on a journey to Fort Kochi to inform Hari's mother about the suicide. On the way, they meet Ramachandran Mokeri, played by himself, at a street theatre camp. He also joins the group, and the journey continues. As they proceed, they gather more friends, who might have known Hari. By the time the group reaches Fort Kochi, travelling through Beypore, Kodungallur, Vypin, etc.-locations which are important for the history of Kerala as well as the people's struggles in the state that the film wants to tell-a collective has been formed. When Purushan informs Hari's mother about the death, she asks: "Wasn't it a suicide?" The narrative part of the film ends with a collective being formed around Hari's mother. After this, we are shown Purushan's mother and girlfriend watching the film in an open ground along with a crowd.

\section{The Artist as a Young Romantic Revolutionary Hero}

In this section, I offer a discussion of Hari as a young romantic revolutionary who breaks free from the earlier representation of revolutionaries or communist heroes in Malayalam cinema. Even though there have been a few films such as Kabani Nadi Chuvannappo/ (When the River Kabani Turned Red, dir. P.A. Backer, 1975), Panchagni (Five Fires, dir. M.T. Vasudevan Nair, 1986), Aranyakam (Forest, dir. Hariharan, 1988), Gulmohar (Flame Tree, dir. Ranjith, 2008), Thalappavu (Headgear, dir. Madhupal, 2010) that has the Naxalite movement in Kerala as the backdrop, a distinct genre like the Naxalite film in Telugu did not take root in Malayalam cinema. Writing in the context of Telugu cinema, S.V. Srinivas defines the Naxalite film as "a low budget genre that features Naxalites as protagonists. Armed squads or Naxalites are often seen performing vigilante action against landlords, corrupt police officials, or politicians and indulging in a variety of populist actions" (Srinivas 2009:258). One may argue that there has been a diverse set of films in Malayalam which can be collectively called "red cinema" which would include the early Communist melodramas, the mass films of I.V. Sasi and T. Damodaran duo, the "art" films that talk about Left politics, the new "comrade films", etc.

The communist hero has found a place in Malayalam cinema from its early period itself as is evident from the early political melodramas associated with the Left such as Mudiyanaya Puthran (The Prodigal Son, dir. Ramu Kariat, 1961), Mooladhanam (Capital, dir. P. Bhaskaran, 1969), Ningalenne Communistakki (You Made Me a Communitst, dir. Thoppil Bhasi, 1970), etc. In these melodramas, the transformation of the communist hero takes place in the realms of familial relations and domesticity. In fact, Mukhamukham (Face to Face, dir. Adoor Gopalakrishnan, 1984), a film that came out two years before Amma Ariyan offers a critique of the melodramatic construction of the communist hero in Malayalam cinema. However, in Amma Ariyan, the romantic hero's transformation is mediated by the political activism of the period.

The journey that the group undertakes to inform Hari's mother about his is interspersed with the memories that the various people have of Hari, and it is through these memories that we get a picture of the person who committed suicide. V.C. Harris has discussed the similarities between Amma Ariyan and Mukhamukham in terms of the making of the image. "The image of the protagonist is largely built up by the people around him" (Harris, 1989, p. 50). The picture of Hari that emerges from these memories is that of a confused artist, a tabla player who is not entirely politicized. When Hari is first introduced to the audience through someone's memory, he is 
playing the tabla at a religious occasion. When Hari's room is shown, the walls are adorned with posters of cricketers and film stars. However, gradually these posters are replaced by the posters of revolutionary icons like Che Guevara, Karl Marx, and Mao Tse-tung. His friend presents him as someone who is totally confused. From someone who refused to play the tabla during political programmes, Hari is transformed into a radical Left activist.
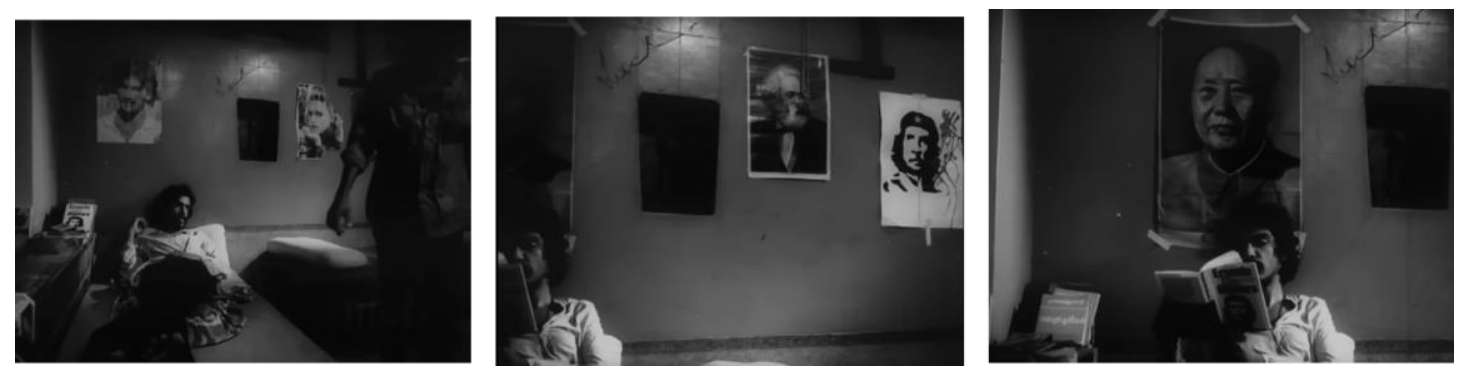

Figure 1: Screen grabs from Amma Ariyan

The linearity of the narrative is broken through the insertion of flashbacks which presents various people's memories. Ayyappan, his roommate who has played a significant role in politicizing Hari, remembers Hari as a totally confused person. However, the image of Hari that we get from all the narratives put together is someone who is transformed from a carefree young man who adored cricket players and pop culture figures to one who involves himself in a police station attack and seizes arms from there. In fact, it is after his involvement in the police station attack and his eventual arrest that he chooses suicide for a heroic redemption. It may appear that it is the loss of the medium of art that must have led to his suicide. From a friend's recollection, we see Hari breaking a musical instrument. However, instead of seeing the suicide as an individual response, one must situate it in the larger context of the relationship between death and revolution.

It is important to note here that it is through the suicide of an artist that John Abraham chose to tell the story of the radical Left movement in Kerala. Given that it was mostly the youth and the artists who were drawn to the radical Left movement, choosing an artist as the central figure has significance in the context of debates around an artist's commitment to revolution or social change. In the film, we hear the members of the group reciting the poem "Apolitical Intellectuals" by the Guatemalan poet Otto Rene Castillo. The moment at which the poem is recited in the film is interesting. What follows the recital of the poem in the film is the sequence where the people of Kottappuram raided the shops of the hoarders who had increased the prices of essential provisions. This struggle was in fact spearheaded by the young activists of Janakeeya Samskarika Vedi. Beena Paul, the editor of Amma Ariyan says, "that shop-raiding sequence is an exact reconstruction of what actually happened in Kottapuram around that time. The uniqueness of that scene is in that John got all of the original people involved in the incident to act in that, including the shopkeeper" (Praveen, 2012). Through the poem, the film tries to bring home the point about the need for intellectuals and cultural activists to join hands with people in their struggle for social change. The poem can be seen as an invitation to take part in collective struggles rather than think of the failures of the period in individual terms.

At this point it is essential to bring a comparison between Hari in Amma Ariyan and the protagonists of two other films from the long 1970s: P.A. Backer's Kabani Nadi Chuvannappo/and K. Raveendran's Iniyum Marichittillatha Nammal (1980). Iniyum Marichittillatha Nammal was an 
attempt to explore the lives of "a youth caught between The Legends of Khasak and The Communist Manifesto, mixed up with existentialism and extremist politics" (Venkiteswaran, 2013, p. 14). For Raveendran, the filmmaker, Iniyum Marichittillatha Namma/ was

an attempt to deal with the disputes and ambiguities within and the decay of the New Left thoughts that emerged in Kerala and across India, post-1968. During the Emergency in 1975, I happened to travel across India. Wherever I went, I could meet groups of youngsters who were products of this political instability: those who thought they should fight against things, but still couldn't do anything much. They had to be mute witnesses of that historical juncture (Raveendran, 1989, p. 213).

Kabani Nadi Chuvannappol (When the River Kabani Turned Red, dir. P.A. Backer, 1975), made during the Emergency can be seen as a precursor to the tradition of what may be called an independent Left cinema in Kerala with broad affinities with the New Left, if not with the radical Left. Kabani Nadi Chuvannappo/tells the story of a Naxalite activist, a romantic revolutionary, who is hunted down by the state. While the youngsters in Iniyum Marichittillatha Nammal, are passive the hero of Kabani Nadi Chuvannappo/ is a romantic revolutionary who is moved by the "duty to revolt", despite the widespread repression of radical Left activists of the time. In both Kabani Nadi Chuvannappol and Amma Ariyan, through death, and suicide, which come as a result of their revolt, the heroes of these two films integrate themselves into the large pantheon of revolutionaries across the world.

\section{Murder, Suicide, Madness: The Vanquished and the Remnants of a Radical Past}

I have suggested that the film can be seen as an exploration of the remnants of a radical past. While the film offers a commentary on the limitations of the various people's struggles that it documents, the radical past is not looked at from a position of despair, but with a melancholic vision that contains redeeming possibilities. As Enzo Traverso argues, "left melancholy has always focused on the vanquished. It perceives the tragedies and the lost battles of the past as a burden and a debt, which are also promise of redemption" (Traverso, 2016, p. xv). The focus on the vanquished is integrated into the diegesis of the film. The film focusses on what remains or what is left behind, both literally and metaphorically. Rajan Krishnan (2013) has pointed out how the camera focusses on who is left behind by lingering on even after the main action in the scenes is over. For instance, we see the camera still focusing on Purushan's mother and girlfriend after he leaves them, we see the camera's focus on the cow, on the notices of the strike at the medical college, etc. The camera's focus on what is left behind relates to the film's exploration of what remains of the radical Left movement.

In one of the early sequences in the film, after the dead body's identity is established, we hear the rumination of one of the characters about what we get back from the revolution. He ruminates about the violent deaths and police brutalities. What the movement left behind is shattered skulls, lacerated hearts, etc., and unfulfilled dreams. We see the film constantly expressing anxiety over so many young people committing suicide. We also see Purushan's rumination over death as he climbs the hill where Hari committed suicide, with Neruda's poem "Death Alone" in the 
soundtrack. In fact, John Abraham himself has said that it was the suicide of many young Leftwing activists that made him think of making a film like Amma Ariyan. John Abraham says:

Amma Ariyan begins with a suicide. During the mid-1970s, a few young Naxalites whom I knew committed suicide. That disturbed me a lot. They were ordinary people. They were intelligent, thinking people, studying Medicine and Engineering. I thought about this spate of suicides and the reason behind them. They were idealists and Naxalites; but somewhere along the way, they must have felt something is not right. There must have been various depressing elements within their own Party. That is how the film begins (Abraham, 2011, p. 128-131).

In his discussion of the film $A$ Grin Without a Cat (Chris marker, 1977) which captures the mood of the global movements in the 1960s and 1970s, Traverso writes that "the film is punctuated with images of burials ... which suggest a symbiotic relationship between revolution and death. But far from symbolizing the end of a communist hope, such mass funerals are experienced as one of its expressions" (Traverso, p. 106). The suicide Amma Ariyan should be seen in terms of an affirmation of the validity of the revolutionary ideal. While the period of 1970 s is full of death, suicide, state brutality, etc. which the film documents, they do not negate the radical ideal.

The excavation that the film performs, through a revisiting of the perceived failures as well as what gets constituted through the journey, is to look for redeeming things in the same ruins. Michael Löwy argues that "the history of socialism over the last two centuries has been a constellation of tragic and often bloody defeats. Yet this does not lead to acceptance of the established order quite the opposite". He further adds that "the memory of ... defeats ... and solidarity with the defeated nourish revolutionary history like an invisible underground river" (Lowy, 2017). This, I argue, needs to be seen in the context of the perceived resurgence of communist desire evidenced by the emergence of "red films" in Malayalam in recent times. In his discussion of melancholy images, Enzo Traverso argues that "realms of memory fulfill the need for preserving an affective relation with an exhausted past threatened with oblivion". He further adds, through an engagement with Walter Benjamin, that "realms of memory are relics, dead objects captured by a contemplative, melancholic gaze, 'in order to redeem them'".

\section{The Emergence of the Collective and the Future of Politics}

In addition to offering a melancholy criticism of the past "failures" of the radical Left movement in Kerala that identifies "empathetically with the vanquished of history" (Traverso, 2017, p. xv), the film also elaborates a future politics. As Walter Benjamin has argued, "the past carries with it a temporal index by which it is referred to redemption. There is a secret agreement between past generations and the present one" (Benjamin, 1999, p.254). The re-assessment of the radical past that the film undertakes can be seen as a search for redemptive elements. As discussed earlier, the journey that Purushan and the team undertakes is interspersed with accounts of various people's movements, with an appraisal of the "success" and "failure" of these movement towards the end of the film. There is an acknowledgement that the victories of the people's struggles were short-lived, and that they were not transformed into larger collective struggles. While this may appear as a harsh critique of the radical Left movement, seen from the perspective of a melancholy 
criticism, the commentary in the film acquires a different dimension that leads to a discussion of the future rather than an obsession with the past.

While the cultural activism of the period may have had its limitations, John Abraham's model of filmmaking elaborates a new model of politics that acknowledges diverse struggles as well as the need for collectives. The argument about the refusal to "resign to reality" even at the face of defeats can be extended to John Abraham's filmmaking practices as well. Abraham's aborted attempt to make a film based on the historic peasant revolt in Kayyur in 1941 in present-day Kerala, an important episode in the history of the Communist movement in Kerala, deserves a brief discussion in this regard. After the legendary filmmaker Mrinal Sen withdrew from the project to make a film on the Kayyur revolt, John Abraham was approached by Kaviyoor Balan, who was the first secretary of Janakeeya Samskarika Vedi, to make a film on Kayyur. It is after the failure of the Kayyur project that John Abraham turned to the formation of the Odessa Collective. Benedict Varghese has argued that Amma Ariyan was born "from the ashes: of the Kayyur film project. If John Abraham and the group had succeeded in making the film on the Kayyur revolt as a people's cinema, Amma Ariyan might not have happened. According to Varghese, the project to make a film on Kayyur "was started as part of an attempt to create a broader-Left platform for dialogue among all left leaning factions, including the conventional Left party activists (Varghese, 2011, p. 229).

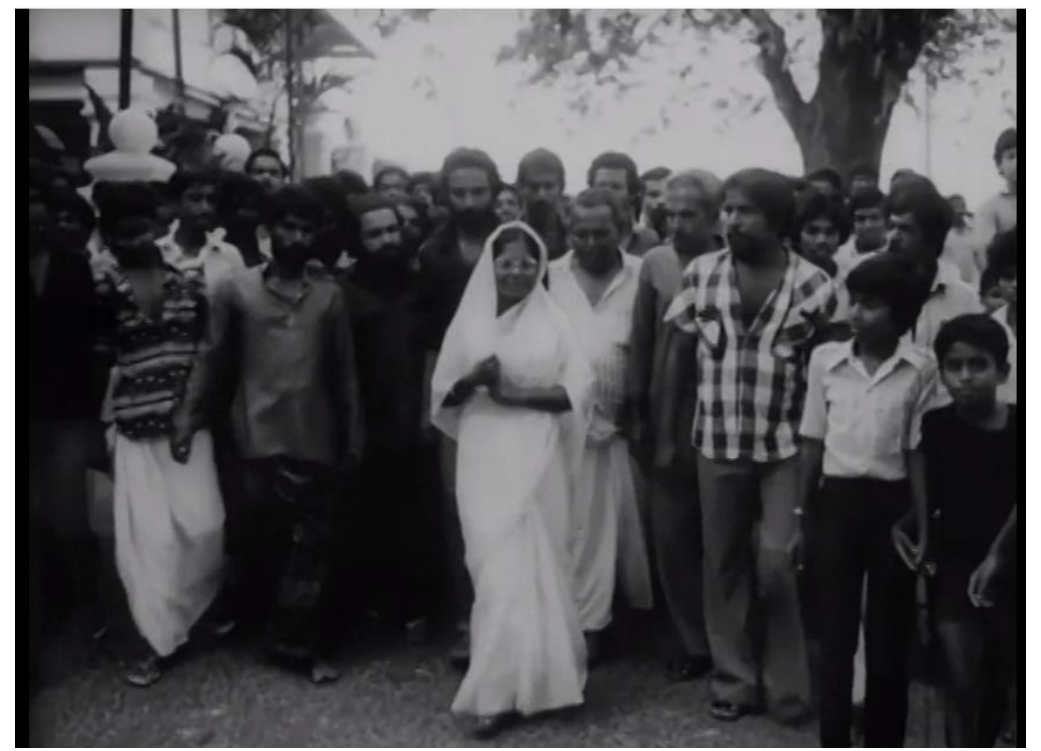

Figure 2: Screen grab from Amma Ariyan. Towards the end of the narrative of the film, a collective gets formed with Hari's mother at the centre

As is evident from the above discussion, both within the diegetic field of the film and in the wider network of relationships around the production and distribution of the film, there is an elaboration of a politics in which the collective acquires particular significance. As Rajan Krishnan argues, "the text of Amma Ariyan and the manner in which it was made were part of the same idea, which is the emergence of a collective" (Krishnan, 2011, p. 41). I have earlier hinted that Odessa was a unique experiment in filmmaking and distribution even though the existence of a strong film society movement enabled one sort of a collective that could undertake film production and distribution. It may be argued that both in terms of production and distribution, and thematic 
concerns, the film offers a model for the future of a radical politics in which a larger alliance among various people's movements and the formation of collectives occupy a significant space. The model of filmmaking and distribution that John Abraham and Odessa Collective adopted exemplifies this politics.

\section{Conclusion}

As suggested in the beginning of this article, the discussions on the 1970s revolve around the question of nostalgia which is seen as an impediment for a radical politics. The period is seen as a haunted one where no one wants to tread. However, in the light of the recent scholarship on Left melancholia, one may examine how a re-assessment of the haunted past through the cultural productions of the time offers a window to the future. The emergence of many writings in Malayalam in the recent past that refer to the period, particularly first-person narratives, allows for a re-look at the period to unearth the hope that the period generated which may sustain a utopian imagination. Such an endeavor allows for a rethinking of nostalgia and its relationship with melancholy and utopian imagination.

\section{Funding Disclosure/Acknowledgement}

The research for this article is partly funded by the Research Initiation Grant, BITS Pilani.

\section{References}

Abraham, J. (2011). "Ente Cinemkalakk Pinnil" (Behind my Films). In K. N. Shaji, ed, John Abraham. Chintha Publishers, pp.128-131.

Abraham, J. (1986). Amma Ariyan. [Motion Picture]. India: Malayalam.

Backer, P.A. (1975). Kabani Nadi Chuvannappo/ [Motion Picture]. India: Malayalam.

Benjamin, W. (1999). Illuminations: Essays and Reflections. Schocken Books.

Bonnett, A. (2010). Left in the Past: Radicalism and the Politics of Nostalgia. Continuum.

Bhasi, Thoppil. (1970). Ningalenne Communistakki [Motion Picture]. India: Malayalam.

Bhaskaran, P. (1969). Mooladhanam [Motion Picture]. India: Malayalam.

Brown, W. (1999). "Resisting Left Melancholy". Boundary 2, 26.3 (Autumn), pp. 19-27.

Dean, J. (2018). The Communist Horizon. Verso.

Gopalakrishnan, Adoor. (1984). Mukhamukham [Motion Picture]. India: Malayalam.

Harris, V.C. (1989). "On Films, Structure and Ideology". Deep Focus, 2.1, pp. 48-54.

Joseph, J. (2019). "Cinema and the political in Kerala: On Mukhamukham and Amma Ariyan". Studies in South Asian Film \& Media, 10(2), 149-161. https://doi.org/10.1386/safm_00011_1

Kariat, Ramu. (1961). Mudiyanaya Puthran [Motion Picture]. India: Malayalam. 
Krishnan, R. (2011). "John Abraham: Cinema and the Idea of the Collective". Journal of the Moving Image, vol. 10, pp. 40-50.

Löwy, M. (2017, June 22). "An Invisible Underground River: On Left-Wing Melancholia". Versobooks.Com. https://www.versobooks.com/blogs/3289-an-invisible-underground-river-on-left-wingmelancholia

Parameswaran, A. (2015). "Contemporaneity and the Collective: The Reportage in Amma Ariyan". In Satheese Chandra Bose and Shiju Sam Varghese, eds, Kerala Modernity: Ideas, Spaces and Practices in Transition. Orient Blackswan, pp. 109-25.

Praveen, S. R. (2012, June 25). "Yours truly John Abraham". The Hindu. https://www.thehindu.com/todayspaper/tp-national/tp-kerala/yours-truly-john-abraham/article3567578.ece

Rajadhyaksha, A., and Willemen, P. (1999). Encyclopaedia of Indian Cinema. British Film Institute.

Raveendran. (1980). Iniyum Marichittillatha Nammal. [Motion Picture]. India: Malayalam.

Raveendran. (1989) "Cinemayile Charithraparatha" (Historicity in Cinema). Odessa Journal, issue 4, pp. 20718.

Sreejith, K. (2005). "Naxalite Movement and Cultural Resistance: Experience of Janakiya Samskarika Vedi in Kerala (1980-82)". Economic and Political Weekly, 40.50, pp. 5333-7.

Srinivas, S.V. (2009). Megastar: Chiranjeevi and Telugu Cinema after N.T. Rama Rao. Oxford University Press.

Traverso, E. (2021). Left-Wing Melancholia: Marxism, History, and Memory. Columbia University Press.

Varghese, Benedict. (2011). Rethinking religion redefining politics Malayalam cinema 1970s 90s and beyond. Unpublished Ph.D. Dissertation, Tata Institute of Social Sciences

Venkiteswaran, C.S. (2013). "Raveendrante Chalachithrangal - Vargha Bhoopadangal" (Raveendran's Films - the Cartography of Class). In C.S. Venkiteswaran, ed, Raveendrante Thirakkathakal (Raveendran's Screenplays). Mathrubhumi Books, pp. 9-20.

P. Muhammed Afzal is an Assistant Professor of Cultural Studies in the Department of Humanities and Social Sciences, Birla Institute of Technology and Science, Pilani (BITS Pilani), Pilani, Rajasthan. His areas of research interests include Malayalam Cinema, Intellectual and Cultural History of the Left in India, Popular Culture and Popular Politics, Cultural Studies in Asia, and Language Politics. 